\title{
Review
}

\section{Deficit irrigation as an on-farm strategy to maximize crop water productivity in dry areas}

\author{
Sam Geerts*, Dirk Raes \\ K.U.Leuven (University of Leuven), Division of Soil and Water Management, Celestijnenlaan 200 E, B-3001Leuven, Belgium
}

\section{A R T I C L E I N F O}

\section{Article history:}

Received 9 May 2008

Accepted 14 April 2009

Available online 14 May 2009

\section{Keywords:}

Water use efficiency

Crop evapotranspiration

Water stress

Arid regions

Water production function

\begin{abstract}
A B S T R A C T
Deficit irrigation (DI) has been widely investigated as a valuable and sustainable production strategy in dry regions. By limiting water applications to drought-sensitive growth stages, this practice aims to maximize water productivity and to stabilize - rather than maximize - yields. We review selected research from around the world and we summarize the advantages and disadvantages of deficit irrigation. Research results confirm that DI is successful in increasing water productivity for various crops without causing severe yield reductions. Nevertheless, a certain minimum amount of seasonal moisture must be guaranteed. DI requires precise knowledge of crop response to drought stress, as drought tolerance varies considerably by genotype and phenological stage. In developing and optimizing DI strategies, field research should therefore be combined with crop water productivity modeling.
\end{abstract}

(c) 2009 Elsevier B.V. All rights reserved.

\section{Contents}

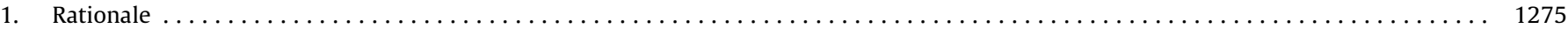

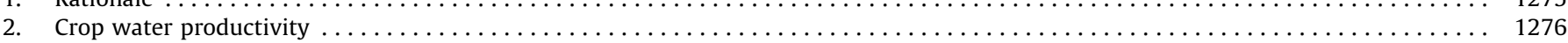

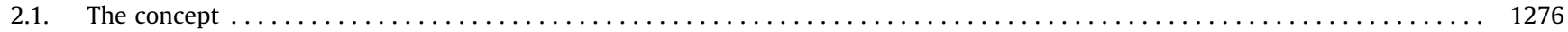

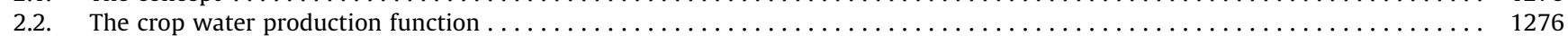

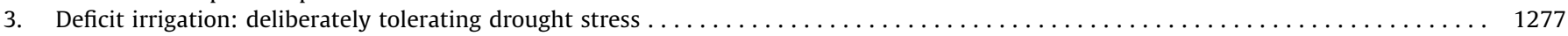

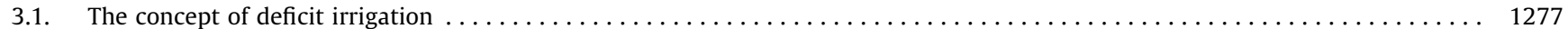

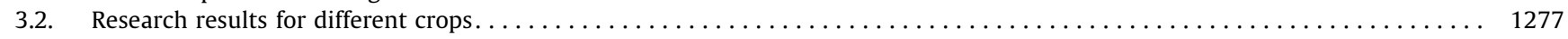

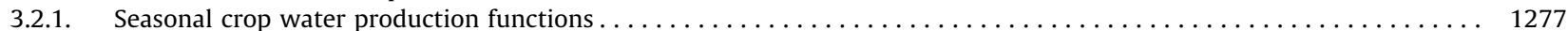

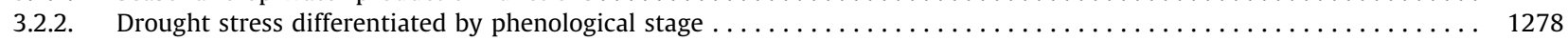

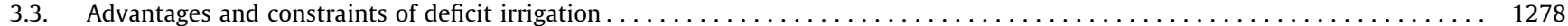

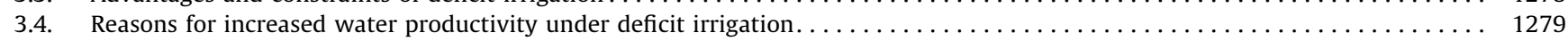

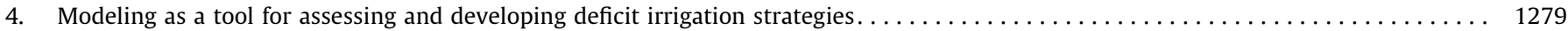

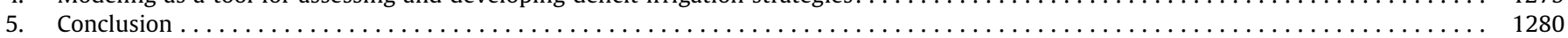

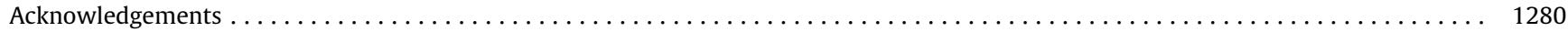

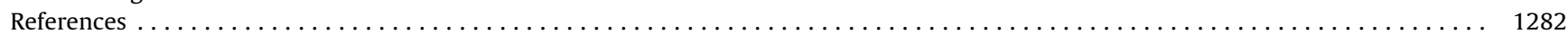

\section{Rationale}

To sustain the rapidly growing world population, agricultural production will need to increase (Howell, 2001), yet the portion of fresh water currently available for agriculture (72\%) is decreasing (Cai and Rosegrant, 2003). Hence, sustainable methods to increase crop water productivity are gaining importance in arid and semi-

\footnotetext{
* Corresponding author. Tel.: +32 163297 54; fax: +32 16329760 .

E-mail addresses: sam.geerts@biw.kuleuven.be, samgeerts@yahoo.com (S. Geerts).
}

arid regions (Debaeke and Aboudrare, 2004). Traditionally, agricultural research has focused primarily on maximizing total production. In recent years, focus has shifted to the limiting factors in production systems, notably the availability of either land or water. Within this context, deficit irrigation (DI) has been widely investigated as a valuable strategy for dry regions (English, 1990; Pereira et al., 2002; Fereres and Soriano, 2007) where water is the limiting factor in crop cultivation. We review recent research on the maximization of productivity per unit of water by DI and we discuss crop water productivity modeling as a tool for assessing and designing DI strategies. 


\section{Crop water productivity}

\subsection{The concept}

Crop water productivity (WP) or water use efficiency (WUE), as reviewed by Molden (2003), is a key term in the evaluation of DI strategies. Water productivity with dimensions of $\mathrm{kg} \mathrm{m}^{-3}$ is defined as the ratio of the mass of marketable yield $\left(Y_{\mathrm{a}}\right)$ to the volume of water consumed by the crop $\left(\mathrm{ET}_{\mathrm{a}}\right)$ :

$\mathrm{WP}=\frac{Y_{\mathrm{a}}}{\mathrm{ET}_{\mathrm{a}}}$

$\mathrm{ET}_{\mathrm{a}}$ refers to water lost either by soil evaporation or by crop transpiration during the crop cycle. Since there is no easy way of distinguishing between these two processes in field experiments, they are generally combined under the term of evapotranspiration (ET) (Allen et al., 1998).

In water-scarce regions, crops with high WP should be preferred, although this is not the only factor. Indeed, while high-energy fruit and grain crops (e.g. crops with high protein content) may have a lower absolute WP value (Steduto and Albrizio, 2005), their nutritional value is higher, which should be considered when assessing these crops for use in drought-prone areas. WP values reported in literature vary according to whether authors express the denominator as the amount of water applied (the sum of rainfall and irrigation) or as the amount of water transpired (unproductive soil evaporation is not taken into account).

\subsection{The crop water production function}

The crop water production function (CWP function) expresses the relation between obtained marketable yield $\left(Y_{\mathrm{a}}\right)$ and the total amount of water evapotranspired $\left(\mathrm{ET}_{\mathrm{a}}\right.$ ) (Stewart et al., 1977; Hexem and Heady, 1978; Doorenbos and Kassam, 1979; Taylor et al., 1983). The highest water efficiency level in the CWP function is determined using WP as a benchmark. As shown in Fig. 1, the CWP function has a logistic shape (Hanks et al., 1969; Hanks, 1974). Its axes are made dimensionless by plotting relative yield ( $Y_{\text {rel }}$ : ratio of actual, $Y_{\mathrm{a}}$, to maximum possible yield under given agronomic conditions, $Y_{\mathrm{m}}$ ) versus relative evapotranspiration

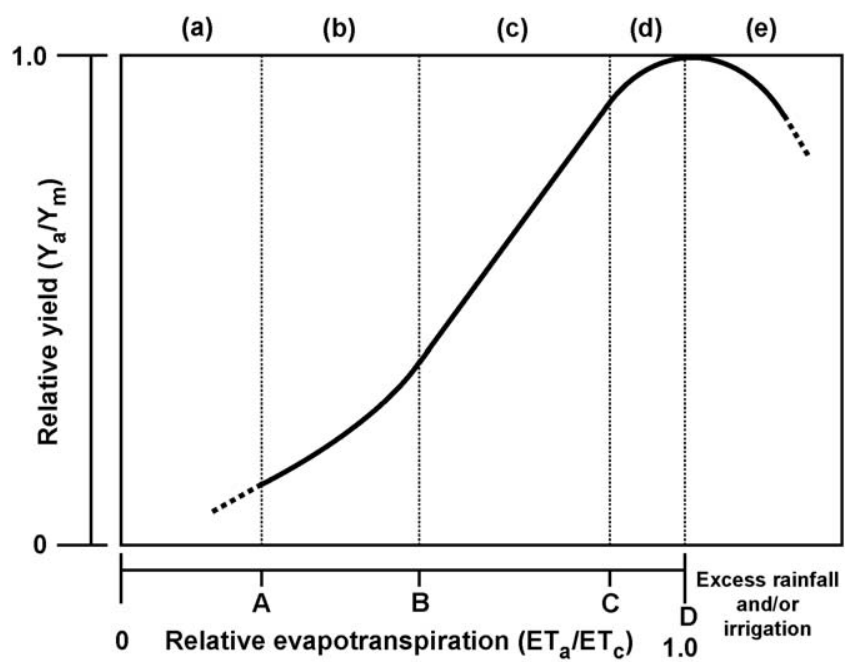

Fig. 1. General shape of a crop water production (CWP) function. Sections (a), (b), $(c),(d)$ and $(e)$ have variable relative widths. Relative yield is the ratio between actual $\left(Y_{\mathrm{a}}\right)$ and potential yield $\left(Y_{\mathrm{m}}\right)$ under given agronomic conditions, while relative evapotranspiration is the ratio between the seasonal amount of water that is evapotranspired $\left(\mathrm{ET}_{\mathrm{a}}\right)$ and seasonal crop water requirements $\left(\mathrm{ET}_{\mathrm{c}}\right)$.
$\left(\mathrm{ET}_{\mathrm{rel}}\right.$ : ratio of actual evapotranspiration, $\mathrm{ET}_{\mathrm{a}}$, to crop $\mathrm{ET}$ under non-stressed, standard conditions, $\mathrm{ET}_{\mathrm{c}}$ ).

Within the CWP function, different sections can be distinguished that may vary in width or that may even be absent:

- Section $a$ : If insufficient water is applied during the crop cycle, the crop will not develop fully, resulting in low-quality yield (shriveled grains or fruits with low market value) or even total loss of yield (Yazar and Sezen, 2006). In this section, WP is very low, and crop yield and WP can only be increased if a considerable amount of water is added and section $b$ is reached (Geerts et al., 2008b). More research is needed to determine this lower limit for various crops.

- Section $b$ : Once a minimum amount of water $(A)$ is guaranteed by residual moisture, rainfall and/or irrigation, yields (and therefore WP) start to increase with increasing water levels. If this section is present, it has a concave shape: increasing water supply will always result in an increased WP from $A$ to $B$.

- Section $c$ : With additional water application, the production function can become nearly linear, with a slope ranging from mild to sharp. Doorenbos and Kassam (1979) point out that the relationship between $Y_{\text {rel }}$ and $\mathrm{ET}_{\text {rel }}$ remains linear for $\mathrm{ET}_{\text {rel }}$ up to a lower limit of 0.5 (point $B$ in Fig. 1), although this lower limit has not been defined for all crops.

- Section $d$ : As observed for many crops, the slope of the CWP function often decreases once $\mathrm{ET}_{\mathrm{rel}}$ is close to 1 . Towards the upper limit of $\mathrm{ET}_{\mathrm{rel}}$, the proportional yield increase per unit ET gradually levels off. Possible reasons are highlighted in Section 3.4 of this review. Section $d$ can be quite large, for crops such as alfalfa, sugar beets (Doorenbos and Kassam, 1979), wheat (Kang et al., 2002; Zhang et al., 2008; Sun et al., 2006) or cotton (Henggeler et al., 2002; Kanber et al., 2006; DeTar, 2008), while it may be almost absent for other crops, such as maize (Kipkorir et al., 2002; Farré and Faci, 2006; Payero et al., 2006). In the literature, this section is often described using combinations of linear functions (i.e. a 'broken stick' model).

When the crop water function includes excess irrigation and/ or rainfall, it has a more pronounced S shape (Fig. 1), creating an additional section:

- Section e: Applying more water than required by $\mathrm{ET}_{\mathrm{c}}$ will not increase yield, as the water is lost through unproductive soil evaporation and/or deep percolation. If too much water is applied, yield might even decline as a result of water logging or leaching of nutrients from the root zone (Sun et al., 2006; Cabello et al., 2009). In this section, irrigation is therefore not required, unless the root zone needs to be leached to reduce salinity.

The level of $\mathrm{ET}_{\mathrm{a}}$ or $\mathrm{ET}_{\text {rel }}$ corresponding with the highest WP can be found by first deriving the WP function (WP versus $\mathrm{ET}_{a}$ ) and then setting the first order derivative of this function to zero. Maximum WP will be found at an $\mathrm{ET}_{\mathrm{a}}$ level within section $c$ or $d$. For the linear section $c$, WP is highest at point $B$ if the extrapolated $Y$-intercept is positive and highest at point $C$ or at a higher ET $_{\mathrm{a}}$ if the extrapolated $Y$ intercept is negative. If maximum WP is located in section $d$ (Eq. (2)), it is located at the point where Eq. (3) equals zero.

$\mathrm{WP}_{\text {section-d }}=a * \mathrm{ET}_{\mathrm{a}}+b+c * \mathrm{ET}_{\mathrm{a}}{ }^{-1}$

$\frac{d\left(\mathrm{WP}_{\text {section-d }}\right)}{d \mathrm{ET}_{\mathrm{a}}}=a-c * \mathrm{ET}_{\mathrm{a}}{ }^{-2}$

The distinction between drought-tolerant and -sensitive crops is not straightforward and depends on the range of $\mathrm{ET}_{\mathrm{a}}$ within which it is defined (Fig. 2). In Fig. 2a maximum WP is reached for $\mathrm{ET}_{\mathrm{a}}$ lower than $\mathrm{ET}_{\mathrm{c}}$, whereas in Fig. 2b WP increases until full water requirements are met (point $D$ ). 
(a) (b)

(a) 1.0

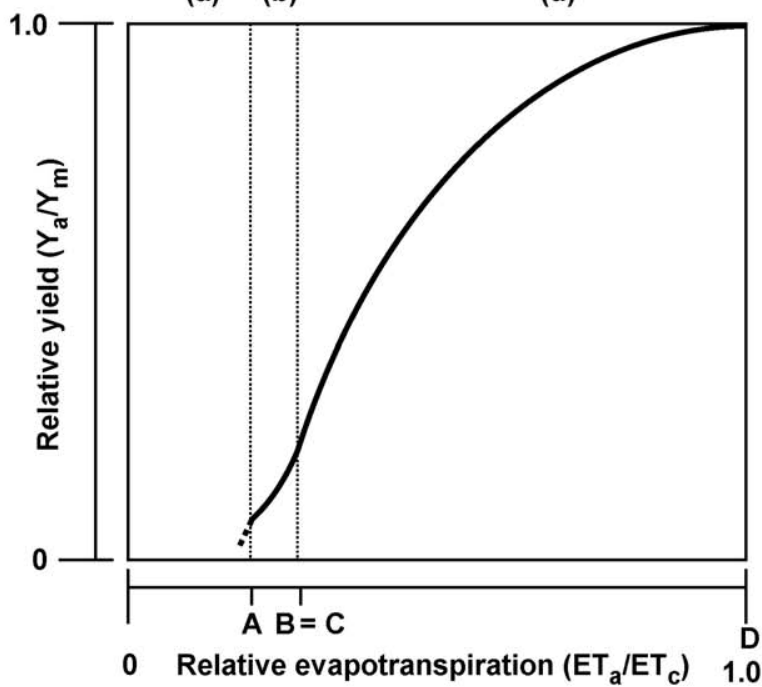

(a)

(b)

(b)

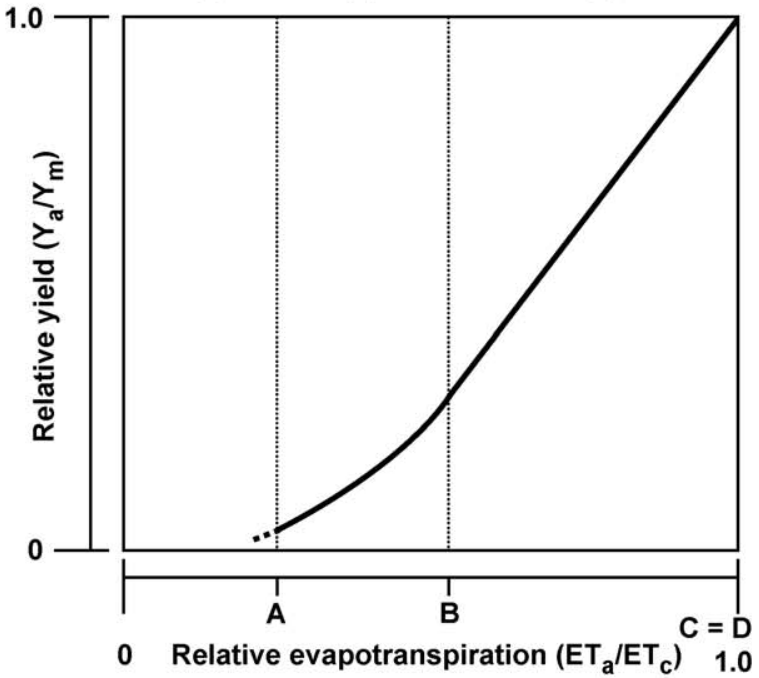

Fig. 2. Possible examples of the shapes of crop water production (CWP) functions for a relatively drought-tolerant (a) and a drought-sensitive (b) crop.

If water shortage $\left(\mathrm{ET}_{\mathrm{rel}}<1\right)$ is evenly distributed over the cropping cycle, the corresponding yield decline can be derived from the seasonal $\mathrm{ET}_{\text {rell }}$. Figs. 1 and 2 indeed show such seasonally determined CWP functions ( $\mathrm{CWP}_{\mathrm{s}}$ function). However, for many crops, drought tolerance varies strongly between growth stages (e.g. Martyniak, 2008). Hence, the CWP functions for these individual growth stages will differ in shape from the $\mathrm{CWP}_{\mathrm{s}}$ function, as the relationship does not account for the effect of the timing of water application. Combining various CWP functions per phenological stage is difficult, in part because there are different combination methods, particularly with linear CWP functions (section c) (Jensen, 1968; Hiller and Clark, 1971; Hanks, 1974; Stewart et al., 1977; Varlev et al., 1996), and each method has advantages and disadvantages. If a combined CWP function $\left(\mathrm{CWP}_{\mathrm{c}}\right.$ function) could be constructed, differentiating drought stress levels over the phenological stages, the general shape would remain similar to that of the $\mathrm{CWP}_{\mathrm{S}}$ function, but increased scatter would make it more difficult to establish general guidelines. In this context, crop water productivity modeling becomes a valuable tool.

\section{Deficit irrigation: deliberately tolerating drought stress}

\subsection{The concept of deficit irrigation}

Deficit irrigation is an optimization strategy in which irrigation is applied during drought-sensitive growth stages of a crop. Outside these periods, irrigation is limited or even unnecessary if rainfall provides a minimum supply of water. Water restriction is limited to drought-tolerant phenological stages, often the vegetative stages and the late ripening period. Total irrigation application is therefore not proportional to irrigation requirements throughout the crop cycle. While this inevitably results in plant drought stress and consequently in production loss, DI maximizes water productivity, which is the main limiting factor (English, 1990). In other words, DI aims at stabilizing yields and at obtaining maximum WP rather than maximum yields (Zhang and Oweis, 1999).

In the literature, the terms 'supplemental irrigation' and 'deficit irrigation' are both used. The first term generally refers to a rain-fed crop receiving additional irrigation during the whole season or during sensitive growth stages, whereas DI generally refers to fully irrigated crops from which water is withheld during certain tolerant growth stages. Both terms are often used interchangeably, which may cause confusion. To avoid ambiguity, "deficit irrigation" is therefore used as the only term throughout this review.

Since drought tolerance varies considerably by genotype and by phenological stage, DI requires precise knowledge of crop response to drought stress for each of the growth stages (Kirda et al., 1999). In addition, correct application of DI requires a thorough assessment of the economic impact of the yield reduction caused by drought stress (English, 1990; English and Raja, 1996; Sepaskhah and Akbari, 2005; Sepaskhah et al., 2006). In areas where water is the most limiting factor, maximizing WP may be economically more profitable for the farmer than maximizing yields (English, 1990). For instance, water saved by DI can be used to irrigate more land (on the same farm or in the water user's community), which - given the high opportunity cost of water - may largely compensate for the economic loss due to yield reduction (Kipkorir et al., 2001; Ali et al., 2007). Even water transfers from water-rich to water-poor areas are possible, as recently demonstrated in California, where DI was used for alfalfa (Hanson et al., 2007). As these examples suggest, DI requires a highly integrated approach to agricultural water policy.

\subsection{Research results for different crops}

\subsubsection{Seasonal crop water production functions}

This section discusses a number of studies in which irrigation applications or levels of tolerated drought stress did not differ between phenological stages. The resulting seasonal $\mathrm{CWP}_{\mathrm{s}}$ function has the theoretical shape shown in Fig. 1, with variable section widths. If different shapes are presented in the literature, this may be due to the fact that the drought stress in the experimental design did not cover the complete relative ET range (Fabeiro et al., 2002; Oweis et al., 2004), that certain sections may have been small or even absent (Payero et al., 2006), or that certain sub-sections were approximated by (a combination of) linear functions.

The general framework presented in Fig. 1 allows us to compare the efficiency of DI versus rain-fed cultivation and/or full irrigation (FI) for a particular crop in a particular location. In many (semi)- 
arid areas, DI is more efficient than rain-fed cultivation. The magnitude of the effect depends on the amount of rain available to meet minimum ET requirements. Only in a few cases is FI required to reach maximum water productivity: this happens when section $d$ is absent and the linear section $c$ has a negative extrapolated $Y$ intercept (cf. Fig. 2b).

For wheat in different locations, the literature on $\mathrm{CWP}_{\mathrm{s}}$ indicates that DI should be preferred over FI due to convex $\mathrm{CWP}_{\mathrm{s}}$ functions (Zhang, 2003; Tavakkoli and Oweis, 2004) or linear CWP functions with maximum WP at sub-maximal $\mathrm{ET}_{\mathrm{a}}$ (Tolk and Howell, 2008). Other crops also respond favorably to a reduction in seasonal irrigation. A convex quadratic $\mathrm{CWP}_{\mathrm{s}}$ function was reported for lentil (Oweis et al., 2004), cotton (Henggeler et al., 2002), green gram (Webber et al., 2006), soy bean (Sincik et al., 2008) and safflower (Lovelli et al., 2007) in varying locations, while a linear $\mathrm{CWP}_{\mathrm{s}}$ function with positive extrapolated Y-intercept (cf. Fig. 2a, linear approximation of upper sub-section of $d$ ) or a convex quadratic $\mathrm{CPW}_{\mathrm{s}}$ function was found for sugarbeet (Bazza (1999) and Doorenbos and Kassam (1979), respectively). For maize grown in different locations, linear $\mathrm{CWP}_{\mathrm{s}}$ functions with a negative extrapolated $Y$-intercept (cf. Fig. 2b) are mostly reported (Farré and Faci, 2006; Payero et al., 2006; Igbadun et al., 2006; Oktem et al., 2003; Tolk et al., 1999). This indicates that, from an agronomical point of view, FI is preferable over DI for maize. The same applies for eggplant (Lovelli et al., 2007).

\subsubsection{Drought stress differentiated by phenological stage}

Table A1 (in Appendix A) summarizes selected research results from recent papers on the use of DI strategies for common (e.g. Zhang, 2003), less common (e.g. Fabeiro et al., 2003a) or horticultural (e.g. Fabeiro et al., 2002) crops. In contrast to the studies discussed in the previous section, these studies differentiated drought stress levels over the season. Results merely derived from simulations are not included in the table. Unless otherwise indicated, the combined CWP functions $\left(\mathrm{CWP}_{\mathrm{c}}\right.$ functions) are based on yield versus total water consumed $\left(\mathrm{ET}_{\mathrm{a}}\right)$ $\left(\mathrm{Mg} \mathrm{ha}^{-1} \mathrm{~mm}^{-1}\right)$. Code (a) means that $\mathrm{CWP}_{\mathrm{c}}$ functions are based on yield versus total water applied and should therefore be regarded as approximate. Indication $(d)$ means that the $\mathrm{CWP}_{\mathrm{c}}$ function was derived from the presented data.

As new research findings are emerging rapidly, the summary needs regular updating. Nevertheless, it is useful in designing and assessing DI strategies. For each of the 18 crops listed, the critical and tolerant phenological stages are reported in addition to the location and the authors of the research. As water is assumed to be the limiting factor, the irrigation strategies that are considered optimal, reflect maximum WP from an agronomic perspective, neglecting specific economic considerations. The $\mathrm{CWP}_{\mathrm{c}}$ function gives a first indication of whether maximal $\mathrm{WP}$ is reached at sub-maximal $\mathrm{ET}_{\mathrm{a}}$ or at $\mathrm{ET}_{\mathrm{c}}$, but due to considerable scatter they should only be considered as approximate. The listing confirms that no single DI strategy applies to all crops, and that tolerable levels of drought and related $\mathrm{CWP}_{\mathrm{c}}$ functions differ significantly between crops (Zwart and Bastiaanssen, 2004).

To illustrate the response of common crops to DI, wheat and maize are discussed:

- Recent findings confirm that DI of wheat can result in an increase of WP without causing substantial yield reductions. In a 4-year field study (1998-2002) of winter wheat in Turkey, well-planned irrigation increased yield by $65 \%$, compared to rain-fed crops and doubled WP compared to rain-fed and fully irrigated crops (Ilbeyi et al., 2006). The positive effect of DI on the WP of wheat was confirmed in experiments carried out in the Loess plateau region of China (Kang et al., 2002; Zhang et al., 2004), in Syria (Zhang and Oweis, 1999) and in Bangladesh (Ali et al., 2007). The latter authors report that DI caused an average increase in yield of 1.6 $\mathrm{Mg} \mathrm{ha}^{-1}$ over the different experimental years in comparison with the rain-fed treatments.

- As for experiments with seasonally distributed drought stress, most authors (Table A1) find that maize responded rather poorly to DI differentiated by phenological stage and suggest that FI is generally preferable. Pandey et al. (2000a,b), for example, conducted experiments on the combined effect of fertilizer application (N-rates) and DI on maize. The highest WP was obtained with FI or deficits limited to the early vegetative stages. This coincided with almost linear $\mathrm{CWP}_{\mathrm{c}}$ functions for the different $\mathrm{N}$-fertilizer levels.

Many less common and horticultural crops listed in Table A1 often respond favorably to DI. Field experiments conducted in the semi-arid to arid Bolivian Altiplano (Geerts et al., 2006b) found that DI was able to stabilize quinoa yields at a level of 1.6 $\mathrm{Mg} \mathrm{ha}^{-1}$ with excellent grain size (Geerts et al., 2008a). This could be achieved by applying only half of the irrigation water required for FI. Irrigation only needed to be applied during the most drought-sensitive stages, i.e. plant establishment, flowering and early grain filling for quinoa (Garcia, 2003; Geerts et al., 2006a). Geerts et al. (2008b) established that in very arid regions, such as the Southern Bolivian Altiplano, several boundary conditions need to be fulfilled to guarantee the success of DI: a minimum of the seasonal crop water requirements must be covered by rainfall and/or irrigation (i.e. section $a$ in Fig. 1) and due attention should be paid to the risk of salinization. An additional beneficial effect of DI on quinoa is that the farmer has greater control of the timing of flowering and harvest, allowing better planning of agricultural activities throughout the season (Geerts et al., 2008c).

When large increases in WP due to DI are observed for trees and deep rooted crops, it should be borne in mind that, unless otherwise indicated, soil water depletion from deeper soil layers is generally not assessed in these experiments (Iniesta et al., 2008). If this additional soil water were taken into account, the actual increase in WP might be lower than reported. Similarly, positive effects of partial root zone drying (PRD) are sometimes exaggerated if differences between initial and final soil water content are not properly considered. In this regard, Liu et al. (2006) report that DI of potato crops had greater effect on WP than PRD, as the latter technique was unable to produce a net WP increase. Wakrim et al., 2005 and Kirda et al., 2005 reject the hypothesis that PRD would cause higher WP than conventional DI for common bean and maize, respectively. On the other hand, positive effects (e.g. on mango fruit size, Spreer et al., 2009) are also reported.

\subsection{Advantages and constraints of deficit irrigation}

The main advantage of DI is that it maximizes the productivity of water. Although a certain reduction in yield is observed, the quality of the yield (e.g. sugar content, grain size) tends to be equal or even superior to rain-fed or FI cultivation (e.g. Fabeiro et al., 2003b; Zhang et al., 2004; Zhang et al., 2006; Marouelli and Silva, 2007; Spreer et al., 2007; Cui et al., 2008; Hueso and Cuevas, 2008).

In areas where water is the limiting factor for crop production, maximizing WP by DI is often economically more profitable for the farmer than maximizing yield. Moreover, irrigated yields can be stabilized at a particular level, guaranteeing a stable income for the farmer and allowing economic planning. An additional advantage is that DI creates a less humid environment around the crop than FI, decreasing the risk of fungal diseases (e.g. Cicogna et al., 2005). 
Reducing irrigation applications over the crop cycle will also reduce nutrient loss through leaching from the root zone, resulting in improved ground water quality (e.g. Ünlü et al., 2006) and lower fertilizer needs on the field. Field observations indicate that crops under serious drought stress during the season might still produce reasonable yields when only a small amount of fertilizer is applied. Over-fertilization may cause crops to be more susceptible to dry spells and may lead to decreased harvest indexes (Garabet et al., 1998). On the other hand, FI can only result in high yields if sufficient N-fertilizer is applied (Garabet et al., 1998; Oweis et al., 1998; Pandey et al., 2000a,b; Geerts et al., 2008a; Di Paolo and Rinaldi, 2008). This indicates that each DI strategy has its optimum fertilizer level (Tavakkoli and Oweis, 2004; Cabello et al., 2009). Hence, DI is most effective if different management factors are considered in parallel (Oweis et al., 1998). What is often labeled as the win-win effect of DI and reduced fertilizer application (Fox and Rockström, 2000, 2003) is the fact that combining DI and optimum fertilizer application leads to a higher yield increase (higher WP) than the sum of the separate yield increases obtained by both factors.

Another benefit of DI is the possibility of controlling sowing dates by irrigation, which allows improved planning of agricultural practices (Corbeels et al., 1998; Oweis et al., 1998). If a common irrigation strategy is adopted in a region, peaks in irrigation water supply will occur during droughtsensitive stages. This might result in under-irrigation of land at the tail end of the irrigation network, causing more severe yield reductions than anticipated. Using modeling, Oweis and Hachum (2001) demonstrate that thanks to the higher level of crop cycle control and the lower sensitivity to climate resulting from (deficit) irrigation, sowing dates can be staggered, thus reducing peak supply by $20 \%$. In this way, basin-wide WP is increased.

Due to drought stress in particular growth stages, the length of the cropping cycle might change under rain-fed cultivation. Farré and Faci (2006) report a delay in flowering ( 7 and 17 days) and maturity (5 and 12 days) for sorghum and maize, respectively, under water deficit conditions. McMaster and Wilhelm (2003) find that drought decreases crop cycle length for wheat and barley. Geerts et al. (2008c) demonstrate that differences in the crop cycle length of quinoa between DI and FI are negligible. Under rain-fed conditions, the crop cycle length of quinoa may increase substantially if severe drought stress occurs before flowering. By controlling the length of the crop cycle (deficit) irrigation allows improved planning of agricultural activities.

Along with these advantages, DI also entails a number of constraints. The use of DI requires that the following conditions are met:

- Crop response to drought stress should be studied carefully (Hsiao, 1973). Determining optimal timing of irrigation applications is particularly difficult for crops with CWP functions in which maximal WP is found within a small optimum range of ET;

- irrigators should have unrestricted access to irrigation water during sensitive growth stages. This is not always the case in large block designs (Zhang, 2003) or during periods of water shortage;

- a minimum quantity of irrigation water should always be available for application (Zhang and Oweis, 1999; Kang et al., 2002; Fereres and Soriano, 2007; Geerts et al., 2008b). This is not always possible in extremely dry regions where irrigation water is scarce (Enfors and Gordon, 2008).

An additional issue refers to individual versus communal benefits. In many communities, the available water supply is inadequate to irrigate all of the available land. In those cases, farmers might consider the communal benefits of allowing suboptimal yields on their individual fields, by practicing DI, so that the water saved might be used to irrigate additional land in the community (Kipkorir et al., 2001). In some areas, water markets and other financial incentives might be implemented to encourage farmers to implement DI strategies that will enhance communal production values.

Finally, DI can only be successful if measures are taken to avoid salinization. By using DI strategies, over-irrigation only rarely occurs. Therefore, leaching of salts from the root zone is lower under DI than under FI (Ragab, 1996; Sarwar and Bastiaanssen, 2001; Kaman et al., 2006; Hsiao et al., 2007; Geerts et al., 2008b).

\subsection{Reasons for increased water productivity under deficit irrigation}

The literature reviewed suggests that increased WP can be attributed to the following reasons:

- water loss through evaporation is reduced;

- the negative effect of drought stress during specific phenological stages on biomass partitioning between reproductive and vegetative biomass (harvest index) (Fereres and Soriano, 2007; Hsiao et al., 2007; Reynolds and Tuberosa, 2008) is avoided, which stabilizes or increases the number of reproductive organs and/or the individual mass of reproductive organs (filling) (Karam et al., 2009);

- WP for the net assimilation of biomass (Eq. (1), with biomass in the numerator and with $T_{\mathrm{a}}$ in the denominator) is increased as drought stress is mitigated or crops become more hardened. This effect is thought to be rather limited given the conservative behavior of biomass growth in response to transpiration (de Wit, 1958; Steduto et al., 2007);

- WP for the net assimilation of biomass is increased due to the synergy between irrigation and fertilization. (Steduto and Albrizio, 2005); This includes cases where irrigation is reduced if fertilizer levels and native fertility are low (Geerts et al., 2008a);

- negative agronomic conditions are avoided during crop growth, such as pests, diseases, anaerobic conditions in the root zone due to water logging, etc. (Pereira et al., 2002; Geerts et al., 2008a).

\section{Modeling as a tool for assessing and developing deficit irrigation strategies}

Examining the yield response to different water applications in field and/or controlled experiments is laborious and expensive. Nor can such experiments cover all possible combinations of differential drought stress or all environmental aspects affecting yield. Moreover, differential response to drought stress during different phenological stages can cause considerable scatter in the $\mathrm{CWP}_{\mathrm{c}}$ function. Against this background, modeling can be a useful tool to study and develop promising DI strategies (Zairi et al., 2000; Kipkorir et al., 2001; Lobell and Ortiz-Monasterio, 2006; Benli et al., 2007; Heng et al., 2007; Lorite et al., 2007; Pereira et al., 2009).

Models allow a combined assessment of different factors affecting yield in order to derive optimal irrigation quantities for different scenarios (Pereira et al., 2002; Liu et al., 2007). Furthermore, they allow differentiating $\mathrm{ET}_{\mathrm{a}}$ between $T$ and $E$ and splitting up crop production in different sub-models (e.g. Raes et al., 2006a; Geerts et al., 2009; Raes et al., 2009; Steduto et al., 2009), which may help elucidate the mechanisms underlying increased WP under DI.

Frequency analysis on long time series of climatic data (Raes et al., 2006b) can lead to the development of a stochastic model 
(Ganji et al., 2006), even on a basin-wide scale (e.g. Ines et al., 2006). By additionally considering the economic risk associated with variable rainfall, Sepaskhah and Akbari (2005) and Sepaskhah et al. (2006) developed a model with probability distributions for the amount of irrigation that should be applied for wheat and cotton in Iran.

It should be mentioned, however, that the quality and general applicability of derived DI strategies largely depends on the validity of the models describing crop growth and yield response to water, and these can only be derived from qualitative field work. Dogan et al. (2007) mention their negative experiences with the modeling of soybean, which made it impossible to derive reliable DI strategies. When using models in different locations and for different crops, one should always be aware of the boundary conditions that were used when a particular model was developed and calibrated.

\section{Conclusion}

Considerable field information is available on the use of deficit irrigation for common and less common crops. In line with the reference works of Hanks et al. (1969), Hanks (1974), Stewart et al. (1977), Doorenbos and Kassam (1979) and Taylor et al. (1983), the relation between crop evapotranspiration and yield is proposed as a framework for evaluating the drought sensitivity of a particular crop during the season or during a specific growth stage. These crop water production functions are non-linear, crop-specific, and they often differ by phenological stage, genotype and location. Calculating the ET level required to reach maximum water productivity within these functions allows a first appraisal of the agronomic usefulness of applying deficit irrigation in a specific situation.

To integrate differential responses of crops to drought stress during different phenological stages, it is suggested that field research be combined with thoroughly calibrated and validated crop water productivity models to further improve promising deficit irrigation strategies derived from field experiments. Additionally, these models may help explain changes in water productivity under different irrigation strategies.

In areas where the available water supply limits agricultural production, deficit irrigation will gain importance over time as farmers strive to increase the productivity of their limited land and water resources. Farmers must choose crops and irrigation strategies carefully to maximize the value of their crop and livestock production activities, while ensuring the sustainability of agriculture. Deficit irrigation will play an important role in farm-level water management strategies, with consequent increases in the output generated per unit of water used in agriculture.

\section{Acknowledgements}

Research funded by a PhD grant of the Flemish Interuniversity Council (VLIR) and by the K.U.Leuven Research Fund for postdoctoral fellowships. We extend our gratitude to Maarten Fauvart and the anonymous reviewers for substantial comments on earlier versions of this article and to Kristin Blanpain for considerable language improvements.

\section{Appendix A}

Table A1 Summary of experimental results on the sensitivity of different crops to drought stress during specific phenological stages, advisable DI strategies and the shape of their combined crop water production functions.

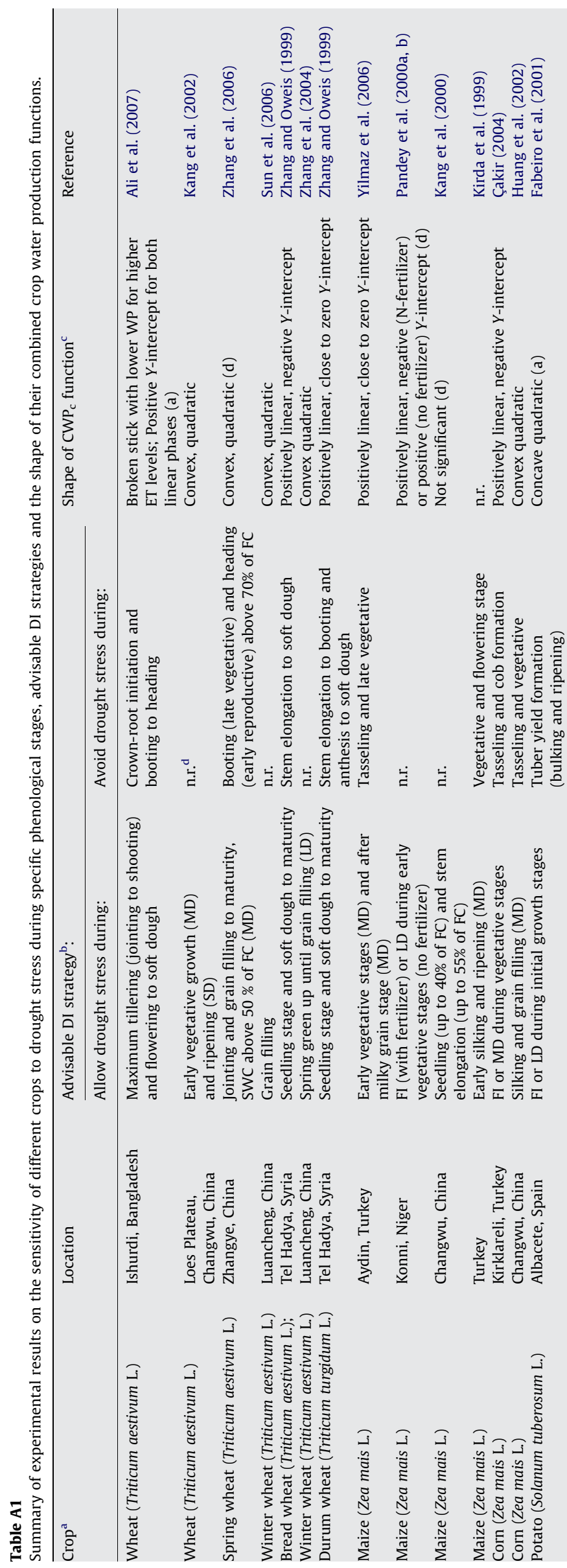




\begin{tabular}{|c|c|c|c|c|c|}
\hline Potato (Solanum tuberosum L.) & Peshawar, Pakistan & Ripening & $\begin{array}{l}\text { Establishment and tuber yield } \\
\text { formation }\end{array}$ & Positively linear, positive $Y$-intercept (d) & Mohsin Iqbal et al. (1999) \\
\hline Potato (Solanum tuberosum L.) & Oregon, USA & n.r. & Tuber bulking & Positively linear, positive $Y$-intercept (a) & Shock and Feibert (2002) \\
\hline Tomato (Solanum lycopersicum L.) & $\begin{array}{l}\text { Brazil district, } \\
\text { Central Brazil }\end{array}$ & Vegetative stages & Fruit development and maturation & Convex quadratic (d) & Marouelli and Silva (2007) \\
\hline Cotton (Gossypium hirsutum L.) & Çukurova, Turkey & Flowering and yield formation & n.r. & Convex quadratic (d) & Kanber et al. (2006) \\
\hline Cotton (Gossypium hirsutum L.) & Çukurova, Turkey & Flowering and yield formation & n.r. & Positively linear, positive $Y$-intercept & Kirda et al. (1999) \\
\hline Cotton (Gossypium hirsutum L.) & $\begin{array}{l}\text { Santiago del Estero, } \\
\text { Argentina }\end{array}$ & Yield formation (MD) and ripening & Vegetative and bud formation & Convex quadratic & Prieto and Angueira (1999 \\
\hline Cotton (Gossypium hirsutum L.) & Bornova-Izmir, Turkey & Boll formation & Vegetative and flowering stages & Positively linear, variable $Y$-intercept & Anaç et al. (1999) \\
\hline Soy Bean (Glycine max L.) & Sanliurfa, Turkey & LD during first 12 days of flowering & $\begin{array}{l}\text { Reproductive stages: full seed (R6), } \\
\text { beginning of pod (R3) and } \\
\text { beginning of seed (R5) }\end{array}$ & Not significant (d) & Dogan et al. (2007) \\
\hline Soy Bean (Glycine max L. Merril) & Bekaa Valley Lebanon & $\begin{array}{l}\text { LD during full bloom (R2) or mature } \\
\text { seed stage (R7) }\end{array}$ & Seed enlargement (R5) & Positively linear, positive $Y$-intercept (d) & Karam et al. (2005) \\
\hline Soy Bean (Glycine max L.) & Greenhouse (Indonesia) & Vegetative stage (up to $0.8 \mathrm{ET}_{\mathrm{c}}$ ) & n.r. & $\begin{array}{l}\text { Logistic, negative } Y \text {-intercept for } \\
\text { linear stage }\end{array}$ & $\begin{array}{l}\text { Bustomi Rosadi } \\
\text { et al. (2007) }\end{array}$ \\
\hline Soy Bean (Glycine max L.) & Turkey & Vegetative stage & Flowering and pod filling & n.r. & Kirda et al. (1999) \\
\hline Common bean (Phaseolus vulgaris L.) & Tumbaco, Ecuador & FI or MD during ripening & Flowering & Positively linear, negative $Y$-intercept (d) & $\begin{array}{l}\text { Calvache and } \\
\text { Reichardt (1999) }\end{array}$ \\
\hline Muskmelon (Cucumis melon L.) & Albacete, Spain & $\mathrm{FI}$, or LD during early vegetative stage & $\begin{array}{l}\text { Flowering, fruit setting } \\
\text { and ripening }\end{array}$ & Concave quadratic (a) & Fabeiro et al. (2002) \\
\hline Garlic (Allium sativum L.) & Albacete, Spain & $\begin{array}{l}\text { Vegetative development }\left(0.7 \mathrm{ET}_{\mathrm{c}}\right) \text {, } \\
\text { bulbification }\left(0.8 \mathrm{ET}_{\mathrm{c}}\right) \text {, ripening }\left(0.5 \mathrm{ET}_{\mathrm{c}}\right)\end{array}$ & Settling & $\begin{array}{l}\text { Concave quadratic (a); for higher } \mathrm{ET}_{\mathrm{c}} \text {, } \\
\text { convex quadratic (d) }\end{array}$ & Fabeiro et al. (2003a) \\
\hline Sunflower (Helianthus annuus L.) & Bekaa valley, Lebanon & Early seed formation & Early and mid flowering & Positively linear, positive $Y$-intercept & Karam et al. (2007) \\
\hline Olive (Olea europea L.) & Benevento, Italy & n.r. & $\begin{array}{l}\text { Beginning of pit hardening to } \\
\text { early fruit veraison }\end{array}$ & $\begin{array}{l}\text { Positively linear, positive } \\
\text { Y-intercept (d) (a) }\end{array}$ & Tognetti et al. (2006) \\
\hline Sugarcane (Saccharum officinarum L.) & $\begin{array}{l}\text { Ferkessédougou, } \\
\text { Ivory Coast }\end{array}$ & Tillering & Stem elongation ('boom’ stage) & n.r. & Pene and Edi (1999) \\
\hline Onion (Allium сера L.) & Woleh, N.E. - Ethiopia & The 2nd of 4 growth stages (MD) & The 3 rd of 4 growth stages & Convex quadratic (a) (d) & Bekele and Tilahun (2007) \\
\hline Groundnut (Arachis hypogaea L.) & Serdang, Malaysia & n.r. & Flowering & n.r. & Ahmad (1999) \\
\hline $\begin{array}{l}\text { Groundnut (Arachis hypogaea L. spp. } \\
\text { Fastigiata var. vulgaris) }\end{array}$ & Junagadh, India & Vegetative phase & n.r. & Convex quadratic (d) & Nautiyal et al. (2002) \\
\hline Alfalfa (Medicago sativa $\mathrm{L}$.) & Davis, USA & n.r. & $\begin{array}{l}\text { FI for subsequent crop after a } \\
\text { crop with DI (limited stress) }\end{array}$ & n.r. & Hanson et al. (2007) \\
\hline Grapevine (Vitis vinifera L. cv. Shiraz) & Waikerie, Australia & Post-set period of berry development & Berry ripening period & n.r. & McCarthy et al. (2002) \\
\hline $\begin{array}{l}\text { Grapevine (Vitis vinifera L. cv. } \\
\text { Sauvignon blanc) }\end{array}$ & $\begin{array}{l}\text { Columbia River } \\
\text { Valley, USA }\end{array}$ & Before veraison $\mathrm{e}^{\mathrm{e}}$ & After veraison ${ }^{\mathrm{e}}$ & n.r. & $\begin{array}{l}\text { Wample and } \\
\text { Smithyman (2002) }\end{array}$ \\
\hline Quinoa (Chenopodium quinoa Willd.) & Altiplano, Bolivia & Vegetative, late grain filling and ripening & $\begin{array}{l}\text { Establishment, flowering and } \\
\text { early grain filling }\end{array}$ & Logistic & $\begin{array}{l}\text { Geerts et al. } \\
\text { (2006a, 2008a, b) }\end{array}$ \\
\hline Sugarbeet (Beta vulgaris L.) & $\begin{array}{l}\text { Central Anatolia, } \\
\text { Turkey }\end{array}$ & Late yield formation and ripening & Emergence and early growth & n.r. & Kirda et al. (1999) \\
\hline
\end{tabular}

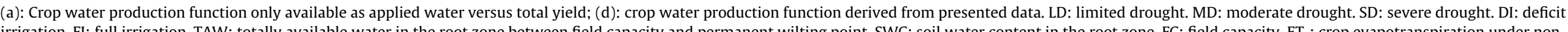

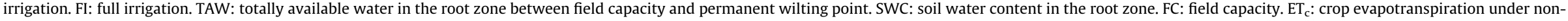
limiting soil water conditions.

a Crop names are presented according to authors' nomenclature.

${ }^{b}$ Advisable DI strategy based on the best water productivity value. Water pricing or product value is not considered.

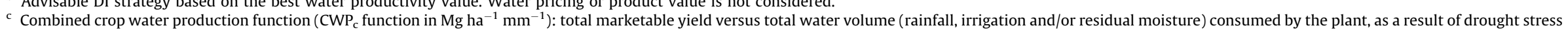
differentiated over the season.

differentiated over the

e n.r.: not reported.
Fruit veraison: change from berry growth to berry ripening. 


\section{References}

Ahmad, A., 1999. Yield response of groundnut grown under rain fed and irrigated conditions. In: Kirda, C., Moutonnet, P., Hera, C., Nielsen, D.R. (Eds.), Crop Yield Response to Deficit Irrigation. Kluwer Academic Publishers, Dordrecht, Boston, London, pp. 128-135.

Ali, M.H., Hoque, M.R., Hassan, A.A., Khair, A., 2007. Effects of deficit irrigation on yield, water productivity, and economic returns of wheat. Agr. Water Manage. 92, 151-161.

Allen, R.G., Pereira, L.S., Raes, D., Smith, M., 1998. Crop Evapotranspiration-Guidelines for Calculating Crop Water Requirements. FAO Irrigation and Drainage Paper 56. FAO, Rome, Italy.

Anaç, M.S., Ali Ul, M., Tuzel, I.H., Anaç, D., Okur, B., Hakerlerler, H., 1999. Optimum irrigation schedules for cotton under deficit irrigation conditions. In: Kirda, C., Moutonnet, P., Hera, C., Nielsen, D.R. (Eds.), Crop Yield Response to Deficit Irrigation. Kluwer Academic Publishers, Dordrecht, Boston, London, pp. 196-212.

Bazza, M., 1999. Improving irrigation management practices with water-deficit irrigation. In: Kirda, C., Moutonnet, P., Hera, C., Nielsen, D.R. (Eds.), Crop Yield Response to Deficit Irrigation. Kluwer Academic Publishers, Dordrecht, Boston, London, pp. 49-70.

Bekele, S., Tilahun, K., 2007. Regulated deficit irrigation scheduling of onion in a semiarid region of Ethiopia. Agr. Water Manage. 89, 148-152.

Benli, B., Pala, M., Stockle, C., Oweis, T., 2007. Assessment of winter wheat production under early sowing with supplemental irrigation in a cold highland environment using CropSyst simulation model. Agr. Water Manage. 93. 45-53.

Bustomi Rosadi, R.A., Afandi, Senge, M., Ito, K., Adomako, J., 2007. The effect of water stress in regulated deficit irrigation on soybean yield (Glycine max [L.]Merr.). Paddy Water Environ. 5, 163-169.

Cabello, M.J., Castellanos, M.T., Romojaro, F., Martinez-Madrid, C., Ribas, F., 2009. Yield and quality of melon grown under different irrigation and nitrogen rates. Agr. Water Manage. 96, 866-874.

Cai, X., Rosegrant, M.W., 2003. World water productivity: current situation and future options. In: Kijne, J.W., Barker, R., Molden, D. (Eds.), Water Productivity in Agriculture: Limits and Opportunities for Improvement. International Water Management Institute (IWMI), Colombo, Sri Lanka, pp. 163-178.

Çakir, R., 2004. Effect of water stress at different development stages on vegetative and reproductive growth of corn. Field Crop Res. 89, 1-16.

Calvache, M., Reichardt, K., 1999. Effects of water stress imposed at different plant growth stages of common bean (Phaseolus vulgaris) an yield and $\mathrm{N}_{2}$ fixation. In: Kirda, C., Moutonnet, P., Hera, C., Nielsen, D.R. (Eds.), Crop yield response to deficit irrigation. Kluwer Academic Publishers, Dordrecht, Boston, London, pp. $121-128$.

Cicogna, A., Dietrich, S., Gani, M., Giovanardi, R., Sandra, M., 2005. Use of meteorological radar to estimate leaf wetness as data input for application of territorial epidemiological model (downy mildew - Plasmopara viticola): agrometeorology 2003. Phys. Chem. Earth 30, 201-207.

Corbeels, M., Hofman, G., Van Cleemput, O., 1998. Analysis of water use by wheat grown on a cracking clay soil in a semi-arid Mediterranean environment: weather and nitrogen effects. Agr. Water Manage. 38, 147-167.

Cui, N., Du, T., Kang, S., Li, F., Zhang, J., Wang, M., Li, Z., 2008. Regulated deficit irrigation improved fruit quality and water use efficiency of pear-jujube trees. Agr. Water Manage. 95, 698-706.

Debaeke, P., Aboudrare, A., 2004. Adaptation of crop management to water-limited environments. Eur. J. Agron. 21, 433-446.

DeTar, W.R., 2008. Yield and growth characteristics for cotton under various irrigation regimes on sandy soil. Agr. Water Manage. 95, 69-76.

de Wit, C.T., 1958. Transpiration and crop yields. Versl. Landbouwk. Onderz. 64.6 Pudoc, Wageningen.

Di Paolo, E., Rinaldi, M., 2008. Yield response of corn to irrigation and nitrogen fertilization in a Mediterranean environment. Field Crop Res. 105, 202-210.

Dogan, E., Kirnak, H., Copur, O., 2007. Deficit irrigations during soybean reproductive stages and CROPGRO-soybean simulations under semi-arid climatic conditions. Field Crop Res. 103, 154-159.

Doorenbos, J., Kassam, A.H., 1979. Yield response to water. FAO Irrigation and Drainage Papers 33. FAO, Rome, Italy.

Enfors, E.I., Gordon, L.J., 2008. Dealing with drought: the challenge of using water system technologies to break dryland poverty traps: local evidence on vulnerabilities and adaptations to global environmental change. Global Environ. Change 18, 607-616.

English, M., 1990. Deficit irrigation. I. Analytical framework. J. Irrig. Drain E. ASCE 116, 399-412.

English, M., Raja, S.N., 1996. Perspectives on deficit irrigation. Agr. Water Manage. $32,1-14$.

Fabeiro, C., Martín de Santa Olalla, F., de Juan, J.A., 2001. Yield and size of deficit irrigated potatoes. Agr. Water Manage. 48, 255-266.

Fabeiro, C., Martín de Santa Olalla, F., de Juan, J.A., 2002. Production of muskmelon (Cucumis melo L.) under controlled deficit irrigation in a semi-arid climate. Agr. Water Manage. 54, 93-105.

Fabeiro, C., Martín de Santa Olalla, F., López Urrea, R., 2003a. Production of garlic (Allium sativum L.) under controlled deficit irrigation in a semi-arid climate. Agr. Water Manage. 59, 155-167.

Fabeiro, C., Martín de Santa Olalla, F., López, R., Domínguez, A., 2003b. Production and quality of the sugar beet (Beta vulgaris L.) cultivated under controlled deficit irrigation conditions in a semi-arid climate. Agr. Water Manage. 62, 215-227.
Farré, I., Faci, J.M., 2006. Comparative response of maize (Zea mays L.) and sorghum (Sorghum bicolor L. Moench) to deficit irrigation in a Mediterranean environment. Agr. Water Manage. 83, 135-143.

Fereres, E., Soriano, M.A., 2007. Deficit irrigation for reducing agricultural water use. Special issue on 'Integrated approaches to sustain and improve plant production under drought stress' J. Exp. Bot. 58, 147-159.

Fox, P., Rockström, J., 2000. Water-harvesting for supplemental irrigation of cereal crops to overcome intra-seasonal dry-spells in the Sahel. Phys. Chem. Earth 25 , 289-296.

Fox, P., Rockström, J., 2003. Supplemental irrigation for dry-spell mitigation of rain fed agriculture in the Sahel. Agr. Water Manage. 61, 29-50.

Ganji, A., Ponnambalam, K., Khalili, D., Karamouz, M., 2006. A new stochastic optimization model for deficit irrigation. Irrig. Sci. 25, 63-73.

Garabet, S., Wood, M., Ryan, J., 1998. Nitrogen and water effects on wheat yield in a Mediterranean-type climate. I. Growth, water-use and nitrogen accumulation. Field Crop Res. 57, 309-318.

Garcia, M., 2003. Agroclimatic study and drought resistance analysis of quinoa for an irrigation strategy in the Bolivian Altiplano. Dissertationes de Agricultura, Faculty of Applied Biological Sciences, K.U.Leuven, Belgium 556.

Geerts, S., Mamani, R.S., Garcia, M., Raes, D., 2006a. Response of quinoa (Chenopodium quinoa Willd.) to differential drought stress in the Bolivian Altiplano: towards a deficit irrigation strategy within a water scarce region. In: Proceedings of the 1st International Symposium on Land and Water Management for Sustainable Irrigated Agriculture. CD-rom.

Geerts, S., Raes, D., Garcia, M., Del Castillo, C., Buytaert, W., 2006b. Agro-climatic suitability mapping for crop production in the Bolivian Altiplano: a case study for quinoa. Agr. Forest Meteorol. 139, 399-412.

Geerts, S., Raes, D., Garcia, M., Vacher, J., Mamani, R., Mendoza, J., Huanca, R., Morales, B., Miranda, R., Cusicanqui, J., Taboada, C., 2008a. Introducing deficit irrigation to stablize yields of quinoa (Chenopodium quinoa Willd.). Eur. J. Agron. $28,427-436$

Geerts, S., Raes, D., Garcia, M., Condori, O., Mamani, J., Miranda, R., Cusicanqui, J., Taboada, C., Vacher, J., 2008b. Could deficit irrigation be a sustainable practice for quinoa (Chenopodium quinoa Willd.) in the Southern Bolivian Altiplano? Agr. Water Manage. 95, 909-917.

Geerts, S., Raes, D., Garcia, M., Mendoza, J., Huanca, R., 2008c. Indicators to quantify the flexible phenology of quinoa (Chenopodium quinoa Willd.) in response to drought stress. Field Crop Res. 108, 150-156.

Geerts, S., Raes, D., Garcia, M., Miranda, R., Cusicanqui, J., Taboada, C., Mendoza, J., Huanca, R. Mamani, A Octavio, C. Mamani, J., Morales, B. Osco, V., Steduto, P. 2009. Simulating yield response of quinoa (Chenopodium quinoa Willd.) to water availability with AquaCrop. Special issue on "Yield Response to Water: Examination of the Role of Crop Models in Predicting Water Use Efficiency" Agron. J 101, 499-508.

Hanks, R.J., 1974. Model for predicting plant yield as influenced by water use. Agron. J. 66, 660-664.

Hanks, R.J., Gardner, H.R., Florian, R.L., 1969. Plant growth-evapotranspiration relations for several crops in the Central Great Plains. Agron. J. 61.1, 30-34.

Hanson, B., Putnam, D., Snyder, R., 2007. Deficit irrigation of alfalfa as a strategy for providing water for water-short areas. Agr. Water Manage. 93, 73-80.

Heng, L.K., Asseng, S., Mejahed, K., Rusan, M., 2007. Optimizing wheat productivity in two rain-fed environments of the West Asia-North Africa region using a simulation model. Eur. J. Agron. 26, 121-129.

Henggeler, J.C., Enciso, J.M., Multer, W.L., Unruh, B.L., 2002. Defici subsurface drip irrigation of cotton. In: Food and Agricultural Organization of the United Nations (FAO) (ed.), Deficit Irrigation Practices. Rome, Italy, pp. 29-38.

Hexem, R.W., Heady, E.O., 1978. Water Production Functions for Irrigated Agriculture. Iowa State University Press, Ames, Iowa, USA.

Hiller, E.A., Clark, R.N., 1971. Stress day index to characterize effects of water stress on crop yields. T. ASAE 757-761.

Howell, T., 2001. Enhancing water use efficiency in irrigated agriculture. Agron. J. 93 pp. 281-189.

Hsiao, T.C., 1973. Plant responses to water stress. Ann. Rev. Plant Physiol. 24, 519 570.

Hsiao, T., Steduto, P., Fereres, E., 2007. A systematic and quantitative approach to improve water use efficiency in agriculture. Irrig. Sci. 25, 209-231.

Huang, M., Zhong, L., Gallichand, J., 2002. Irrigation treatments for corn with limited water supply in the Loess Plateau, China. Can. Biosyst. Eng. 44, 1.29-1.34.

Hueso, J., Cuevas, J., 2008. Loquat as a crop model for successful deficit irrigation. Irrig. Sci. 26, 269-276

Igbadun, H.E., Mahoo, H.F., Tarimo, A.K.P.R., Salim, B.A., 2006. Crop water productivity of an irrigated maize crop in Mkoji sub-catchment of the Great Ruaha River Basin, Tanzania. Agr. Water Manage. 85, 141-150.

Ilbeyi, A., Ustun, H., Oweis, T., Pala, M., Benli, B., 2006. Wheat water productivity and yield in a cool highland environment: Effect of early sowing with supplemental irrigation. Agr. Water Manage. 82, 399-410.

Ines, A.V.M., Honda, K., Gupta, A.D., Droogers, P., Clemente, R.S., 2006. Combining remote sensing-simulation modeling and genetic algorithm optimization to explore water management options in irrigated agriculture. Agr. Water Manage. $83,221-232$

Iniesta, F., Testi, L., Goldhamer, D.A., Fereres, E., 2008. Quantifying reductions in consumptive water use under regulated deficit irrigation in pistachio (Pistacia vera L.). Agr. Water Manage. 95, 877-886.

Jensen, M.E., 1968. Water consumption by agricultural plants. In: Kozlowski (Eds.), Water Deficits and Plant Growth. Vol. II. Plant Water Consumption and Response. Academic Press, New York \& London, pp. 1-22. 
Kaman, H., Kirda, C., Cetin, M., Topcu, S., 2006. Salt accumulation in the root zones of tomato and cotton irrigated with partial root-drying technique. Irrig. Drain. 55 , 533-544.

Kanber, R., Ünlü, M., Koç, D.L., Kapur, B., Tekin, S., Özekici, B., 2006. Efficient water use to sustain irrigated agriculture: deficit irrigation management of cotton, pistachio and maize. In: Proceedings of the 1st International Symposium on Land and Water Management for Sustainable Irrigated Agriculture. CD-rom.

Kang, S., Shi, W., Zhang, J., 2000. An improved water-use efficiency for maize grown under regulated deficit irrigation. Field Crop Res. 67, 207-214

Kang, S., Zhang, L., Liang, Y., Hu, X., Cai, H., Gu, B., 2002. Effects of limited irrigation on yield and water use efficiency of winter wheat in the Loess Plateau of China. Agr. Water Manage. 55, 203-216.

Karam, F., Masaad, R., Sfeir, T., Mounzer, O., Rouphael, Y., 2005. Evepotranspiration and seed yield of field grown soybean under deficit irrigation conditions. Agr Water Manage. 75, 226-244.

Karam, F., Lahoud, R., Masaad, R., Kabalan, R., Breidi, J., Chalita, C., Rouphael, Y., 2007. Evapotranspiration, seed yield and water use efficiency of drip irrigated sunflowe under full and deficit irrigation conditions. Agr. Water Manage. 90, 213-223.

Karam, F., Kabalan, R., Breidi, J., Rouphael, Y., Oweis, T., 2009. Yield and waterproduction functions of two durum wheat cultivars grown under different irrigation and nitrogen regimes. Agr. Water Manage. 96, 603-615.

Kipkorir, E.C., Raes, D., Labadie, J., 2001. Optimal allocation of short-term irrigation supply. Irrig. Drain Syst. 15, 247-267.

Kipkorir, E.C., Raes, D., Massawe, B., 2002. Seasonal water production functions and yield response factors for maize and onion in Perkerra, Kenya. Agr. Water Manage. 56, 229-240.

Kirda, C., Kanber, R., Tülücü, K., Güngör, H., 1999. Yield response of cotton maize, soybean, sugar beet, sunflower and wheat to deficit irrigation. In: Kirda, C., Moutonnet, P., Hera, C., Nielsen, D.R. (Eds.), Crop Yield Response to Deficit Irrigation. Kluwer Academic Publishers, Dordrecht, Boston, London, pp. 21-38

Kirda, C., Topcu, S., Kaman, H., Ulger, A.C., Yazici, A., Cetin, M., Derici, M.R., 2005. Grain yield response and N-fertiliser recovery of maize under deficit irrigation. Field Crop Res. 93, 132-141.

Liu, F., Shahanzari, A., Andersen, M.A., Jacobsen, S.-E., Jensen, C.R., 2006. Effects of deficit irrigation (DI) and partial root drying (PRD) on gas exchange, biomass partioning, and water use efficiency in potato. Scientia Hortic. Amsterdam 109, $113-117$

Liu, J., Wiberg, D., Zehnder, A., Yang, H., 2007. Modeling the role of irrigation in winter wheat yield, crop water productivity, and production in China. Irrig. Sci. $26,21-33$.

Lobell, D.B., Ortiz-Monasterio, J.I., 2006. Evaluating strategies for improved water use in spring wheat with CERES. Agr. Water Manage. 84, 249-258.

Lorite, I.J., Mateos, L., Orgaz, F., Fereres, E., 2007. Assessing deficit irrigation strategies at the level of an irrigation district. Agr. Water Manage. 91, 51-60.

Lovelli, S., Perniola, M., Ferrara, A., Di Tommaso, T., 2007. Yield response factor to water (Ky) and water use efficiency of Carthamus tinctoris L. and Solanum melongena L. Agr. Water Manage. 92, 73-80.

Marouelli, W., Silva, W., 2007. Water tension thresholds for processing tomatoes under drip irrigation in Central Brazil. Irrig. Sci. 25, 411-418.

Martyniak, L., 2008. Response of spring cereals to a deficit of atmospheric precipitation in the particular stages of plant growth and development. Agr. Wate Manage. 95, 171-178.

McCarthy, M.G., Loveys, B.R., Dry, P.R., Stoll, M., 2002. Regulated deficit irrigation and partial rootzone drying as irrigation management techniques for grapevines. In: Food and Agricultural Organization of the United Nations (FAO) (ed.) Deficit Irrigation Practices. Rome, Italy, pp. 79-88.

McMaster, G.S., Wilhelm, W.W., 2003. Phenological responses of wheat and barley to water and temperature: improving simulation models. J. Agr. Sci. 141, 129-147.

Mohsin Iqbal, M., Mahmood Shah, S., Mohammad, W., Nawaz, H., 1999. Field response of potato subjected to water stress at different growth stages. In: Kirda, C., Moutonnet, P., Hera, C., Nielsen, D.R. (Eds.), Crop Yield Response to Deficit Irrigation. Kluwer Academic Publishers, Dordrecht, Boston, London, pp. 213-223.

Molden, D., 2003. A water-productivity framework for understanding and action. In: Kijne, J.W., Barker, R., Molden, D. (Eds.), Water Productivity in Agriculture: Limits and Opportunities for Improvement. International Water Management Institute, Colombo, Sri Lanka, pp. 1-18.

Nautiyal, P.C., Joshi, Y.C., Dayal, D., 2002. Response of groundnut to deficit irrigation during vegetative growth. In: Food and Agricultural Organization of the United Nations (FAO) (ed.), Deficit Irrigation Practices. Rome, Italy, pp. 39-46.

Oktem, A. Simsek, M., Oktem, A.G., 2003. Deficit irrigation on sweet corn (Zea mays saccharata Sturt) with drip irrigation system in a semi-arid region. Agr. Water Manage. 61, 63-74.

Oweis, T., Hachum, A., 2001. Reducing peak supplemental irrigation demand by extending sowing dates. Agr. Water Manage. 50, 109-123.

Oweis, T., Pala, M., Ryan, J., 1998. Stabilizing rain fed wheat yields with supplementa irrigation and nitrogen in a mediterranean climate. Agron. J. 90, 672-681.

Oweis, T., Hachum, A., Pala, M., 2004. Lentil production under supplemental irrigation in a Mediterranean environment. Agr. Water Manage. 68, 251-265.

Pandey, R.K., Maranville, J.W., Admou, A., 2000a. Deficit irrigation and nitrogen effects on maize in a Sahelian environment. I. Grain yield and yield components. Agr. Water Manage. 46, 1-13.

Pandey, R.K., Maranville, J.W., Chetima, M.M., 2000b. Deficit irrigation and nitrogen effects on maize in a Sahelian environment. II. Shoot growth, nitrogen uptake and water extraction. Agr. Water Manage. 46, 15-27.
Payero, J.O., Melvin, S.R., Irmak, S., Tarkalson, D., 2006. Yield response of corn to deficit irrigation in a semiarid climate. Agr. Water Manage. 84, 101-112.

Pene, C.B.G., Edi, G.K., 1999. Sugarcane yield response to deficit irrigation at two growth stages. In: Kirda, C., Moutonnet, P., Hera, C., Nielsen, D.R. (Eds.), Crop Yield Response to Deficit Irrigation. Kluwer Academic Publishers, Dordrecht, Boston, London, pp. 136-147.

Pereira, L.S., Oweis, T., Zairi, A., 2002. Irrigation management under water scarcity. Agr. Water Manage. 57, 175-206.

Pereira, L.S., Paredes, P., Sholpankulov, E.D., Inchenkova, O.P., Teodoro, P.R., Horst, M.G., 2009. Irrigation scheduling strategies for cotton to cope with water scarcity in the Fergana Valley. Central Asia. Agr. Water Manage. 96, 723-735.

Prieto, D. Angueira, C., 1999. Water stress effects on different growing stages for cotton and its influence. In: Kirda, C., Moutonnet, P., Hera, C., Nielsen, D.R. (Eds.), Crop Yield Response to Deficit Irrigation. Kluwer Academic Publishers, Dordrecht, Boston, London, pp. 161-179.

Raes, D., Geerts, S., Kipkorir, E., Wellens, J., Sahli, A., 2006a. Simulation of yield decline as a result of water stress with a robust soil water balance model. Agric. Water Manage. 81, 335-357.

Raes, D., Willems, P., Gbaguidi, F., 2006b. RAINBOW: a software package for hydrometeorological frequency analysis and testing the homogeneity of historical data sets. In: Proceedings of the 4th International Workshop on 'Sustainable management of marginal drylands (SUMAMAD)'.

Raes, D., Steduto, P., Hsiao, T.C., Fereres, E., 2009. AquaCrop-the FAO crop model to predict yield response to water. II. Main algorithms and software description. Special issue on "Yield Response to Water: Examination of the Role of Crop Models in Predicting Water Use Efficiency" Agron. J. 101, 438-447.

Ragab, R., 1996. Constraints and applicability of irrigation scheduling under limited water resources, variable rainfall and saline conditions. In: Food and Agricultural Organization of the United Nations (FAO) (ed.), Irrigation Scheduling: from Theory to Practice. Rome, Italy, pp. 149-165.

Reynolds, M., Tuberosa, R., 2008. Translational research impacting on crop productivity in drought-prone environments. Curr. Opin. Plant Biol. 11, 171-179.

Sarwar, A., Bastiaanssen, W.G.M., 2001. Long-term effects of irrigation water conservation on crop production and environment in semiarid areas. J. Irrig. Drain E. ASCE 127, 331-338.

Sepaskhah, A.R., Akbari, D., 2005. Deficit irrigation planning under variable seasonal rainfall. Biosyst. Eng. 92, 97-106.

Sepaskhah, A.R., Azizian, A., Tavakoli, A.R., 2006. Optimal applied water and nitrogen for winter wheat under variable seasonal rainfall and planning scenarios for consequent crops in a semi-arid region. Agr. Water Manage. 84, 113-122.

Shock, C.C., Feibert, E.B.G., 2002. Deficit irrigation of potato. In: Food and Agricultural Organization of the United Nations (FAO) (ed.), Deficit Irrigation Practices. Rome, Italy, pp. 47-56.

Sincik, M., Candogan, B.N., Demirtas, C., Buyukcangaz, H., Yazgan, S., Goksoy, A.T. 2008. Deficit Irrigation of Soya Bean [Glycine $\max ($ L.) Merr.] in a Sub-humid Climate. J. Agron. Crop Sci. 194, 200-205.

Spreer, W., Nagle, M., Neidhart, S., Carle, R., Ongprasert, S., Muller, J., 2007. Effect of regulated deficit irrigation and partial rootzone drying on the quality of mango fruits (Mangifera indica L., cv. 'Chok Anan'). Agr. Water Manage. 88, 173-180.

Spreer, W., Ongprasert, S., Hegele, M., Wünnsche, J.N., Müller, J., 2009. Yield and fruit development in mango (Mangifera indica L. cv. Chok Anan) under different irrigation regimes. Agr. Water Manage. 96, 574-584

Steduto, P., Albrizio, R., 2005. Resource use efficiency of field-grown sunflower, sorghum, wheat and chickpea. II. Water use efficiency and comparison with radiation use efficiency. Agr. Forest Meteorol. 130, 269-281.

Steduto, P., Hsiao, T.C., Fereres, E., 2007. On the conservative behavior of biomass water productivity. Irrig. Sci. 25, 189-207.

Steduto, P., Hsiao, T.C., Raes, D., Fereres, E., 2009. AquaCrop-the FAO crop model to predict yield response to water. I. Concepts. Special issue on "Yield Response to Water: Examination of the Role of Crop Models in Predicting Water Use Efficiency" Agron. J. 101, 426-437.

Stewart, J.I., Cuenca, R.H., Pruitt, W.O., Hagan, R.M., Tosso, J., 1977. Determination and Utilization of water production functions for principal California crops. W67 Calif. Contrib. Proj. Rep. University of California, Davis.

Sun, H.Y., Liu, C.-M., Zhang, X.-Y., Shen, Y.-J., Zhang, Y.-Q., 2006. Effects of irrigation on water balance, yield and WUE of winter wheat in the North China Plain. Agr. Water Manage. 85, 211-218.

Tavakkoli, A.R., Oweis, T.Y., 2004. The role of supplemental irrigation and nitrogen in producing bread wheat in the highlands of Iran. Agr. Water Manage. 65, 225236.

Taylor, H.M., Jordan, W.R., Sinclair, T.R., 1983. Limitations to Efficient Water Use in Crop Production. American Society of Agronomy, Crop Society of America, Soil Science Society of America, USA.

Tognetti, R., d'Andria, R., Lavini, A., Morelli, G., 2006. The effect of deficit irrigation on crop yield and vegetative development of Olea europaea L. (cvs. Frantoio and Leccino). Eur. J. Agron. 25, 356-364.

Tolk, J.A., Howell, T.A., Evett, S.R., 1999. Effect of mulch, irrigation, and soil type on water use and yield of maize. Soil Till. Res. 50, 137-147.

Tolk, J.A., Howell, T.A., 2008. Field water supply:yield relationships of grain sorghum grown in three USA Southern Great Plains soils. Agr. Water Manage. 95, 13031313.

Ünlü, M., Kanber, R., Senyigit, U., Onaran, H., Diker, K., 2006. Trickle and sprinkler irrigation of potato (Solanum tuberosum L.) in the middle Anatolian region in Turkey. Agr. Water Manage. 79, 43-71.

Varlev, I., Dimitrov, P., Popova, Z., 1996. Irrigation scheduling for conjunctive use of rainfall and irrigation based on yield-water relationships. In: Food and Agri- 
cultural Organization of the United Nations (FAO) (ed.), Irrigation Scheduling: From Theory to Practice. Rome, Italy. pp. 205-214.

Wakrim, R., Wahbi, S., Tahi, H., Aganchich, B., Serraj, R., 2005. Comparative effects of partial root drying (PRD) and regulated deficit irrigation (RDI) on water relations and water use efficiency in common bean (Phaseolus vulgaris L.). Agr. Ecosyst. Environ. 106, 275-287.

Wample, R.L., Smithyman, R., 2002. Regulated deficit irrigation as a water management strategy in Vitis vinifera. In: Food and Agricultural Organization of the United Nations (FAO) (ed.), Deficit Irrigation Practices. Rome, Italy. pp. 89-100.

Webber, H.A., Madramootoo, C.A., Bourgault, M., Horst, M.G., Stulina, G., Smith, D.L., 2006. Water use efficiency of common bean and green gram grown using alternate furrow and deficit irrigation. Agr. Water Manage. 86, 259-268.

Yazar, A., Sezen, S.M., 2006. Effects of full and deficit irrigation on yield and water use efficiency of winter wheat in the arid southeast Anatolia region of Turkey. In: Proceedings of the 1st International Symposium on Land and Water Management for Sustainable Irrigated Agriculture, CD-rom.

Yilmaz, E., Dagdelen, N., Sezgin, F., Bas, S., 2006. Responses of corn (Zea mays L.) to water stress at different growth stages. In: Proceedings of the 1st International Symposium on Land and Water Management for Sustainable Irrigated Agriculture, CD-rom.
Zairi, A., El Amami, H., Slatni, A., Derouiche, A., Pereira, L.S., Rodrigues, P., Texeira, J.L., 2000. Irrigation scheduling strategies for horticultural field crops under limited water availability. Acta Hortic. 537, 503-510.

Zhang, H., 2003. Improving water productivity through deficit irrigation: examples from Syria, the North China Plain and Oregon, USA. In: Kijne, J.W., Barker, R., Molden, D. (Eds.), Water Productivity in Agriculture: Limits and Opportunities for Improvement. International Water Management Institute, Colombo, Sri Lanka, pp. 301-309.

Zhang, H., Oweis, T., 1999. Water-yield relations and optimal irrigation scheduling of wheat in the Mediterranean region. Agr. Water Manage. 38, 195-211.

Zhang, X., Chen, S., Sun, H., Pei, D., Wang, Y., 2008. Dry matter, harvest index, grain yield and water use efficiency as affected by water supply in winter wheat. Irrig. Sci. 27, 1-10.

Zhang, Y., Kendy, E., Qiang, Y., Changming, L., Yanjun, S., Hongyong, S., 2004. Effect of soil water deficit on evapotranspiration, crop yield, and water use efficiency in the North China Plain. Agr. Water Manage. 64, 107-122.

Zhang, B., Li, F.-M., Huang, G., Cheng, Z.-Y., Zhang, Y., 2006. Yield performance of spring wheat improved by regulated deficit irrigation in an arid area. Agr. Water Manage. 79, 28-42.

Zwart, S.J., Bastiaanssen, W.G.M., 2004. Review of measured crop water productivity values for irrigated wheat, rice, cotton and maize. Agr. Water Manage. 69, 115-133. 